\title{
Evidence for autotetraploidy in Plantago media and comparisons between natural and artificial cytotypes concerning cell size and fertility*
}

\author{
Peter Van Dijk† and \\ Wilke Van Delden
}

Department of Genetics, University of Groningen, P.O. Box 14, 9750 AA Haren, The Netherlands

The hypothesis of autotetraploidy in Plantago media $(2 n=12$ and $2 n=24)$ was tested. The two cytotypes are morphologically very similar. Rare $4 X$ and $3 X$ hybrids were obtained in inter-ploidy crosses. The reproductive isolation between $2 X$ and $4 X$ is post-zygotic and can be broken down and introduced by colchicine treatment. The studied diploid and tetraploid populations shared the same alleles for nine allozyme loci. Together this provides strong evidence for autotetraploid origin of tetraploid $\boldsymbol{P}$. media. Fertility of colchicine tetraploids was comparable to natural tetraploids and slightly lower than natural diploids. In contrast to colchicine tetraploids, natural tetraploids did not show gigascharacteristics. Tetraploid hybrids between diploids and natural tetraploids showed partial gigas-characteristics. The possible reasons for the differences in cell size between cytotypes are discussed. Differentiating characters between the natural cytotypes were not affected by colchicine treatment and are therefore not a direct consequence of polyploidization.

\section{INTRODUCTION}

Polyploidy is a remarkably wide-spread phenomenon in plants. Grant (1981) estimated that 47 per cent of the angiosperms are probably of polyploid origin. Polyploidy is even more prominent in the genus Plantago. In more than two thirds of the 122 Plantago species listed in Dietrich (1975) and (1980) polyploid chromosome numbers have been counted. In spite of more than 60 years of polyploid research, the reasons for the evolutionary success still remain largely obscure (Stebbins and Dawe, 1987).

The classification of polyploids is difficult and much discussed (Stebbins, 1971, 1980, 1985; Lewis, 1980; Grant, 1981; Soltis and Rieseberg, 1986). In addition the importance of autopolyploidy in plant evolution is still a matter of much dispute. Clausen, Keck and Hiesey (1945) considered only a few species as true autopolyploids, an opinion shared by Grant (1981). In contrast, Gottschalk (1976) and Lewis (1980) give many examples of supposed autopolyploids to underscore the significance of

\footnotetext{
* Grassland Species Research Group Publication No. 168.

$\dagger$ Present address: Department of Plant Ecology, Institute for Ecological Research, Boterhoeksestraat 22, 6666 GA Heteren, The Netherlands.
}

autopolyploid evolution. According to Stebbins (1971) genome doubling by itself is not a help but a hindrance to evolutionary success. However, Levin (1983) and Cavalier-Smith (1985) consider genome doubling itself a source of evolutionary novelty.

To provide a reliable polyploid phylogeny many different sources of evidence are necessary (Stebbins, 1971). Experimental resynthesis can be seen as strong evidence, but interpretation may be hampered by evolutionary divergence after polyploidization. Here we use the term autopolyploidy to refer to intraspecific polyploidy and allopolyploidy for interspecific polyploidy (Lewis, 1980).

The most universal effects of artificial autopolyploidization are reduced fertility and increased cell and organ sizes (gigas-effects) (Stebbins, 1971; Lewis, 1980). Low fertility, primarily caused by multivalent formation, is expected to constrain autopolyploid evolution. It has been suggested that selection for increased fertility may lead to cytological diploidization in polyploids (DeWet, 1980; Watanabe, 1983). It is therefore of interest to investigate fertility in successful natural autopolyploids. Solbrig (1980) proposed that gigas-characteristics could be of adaptive value for new polyploids. However in a review 
Tanaka (1953) concluded that natural polyploids in general had smaller stomatal guard cells than artificial polyploids. This difference may be interpreted as a difference between new and established polyploids (Trombetta, 1942; Gottschalk, 1976). However, comparisons between diploids and polyploids are often obscured by uncertain phylogynies and by effects of hybridization in the case of allopolyploids. Intra-specific comparisons between natural and artificial autopolyploids are rare; Tanaka (1953) lists only two cases. Direct evidence for reduction of cell size after polyploidization comes from Von Wettstein (1937) who observed a reduction of the cell volumes of artificial autodiploid Bryum to the original haploid level, over a period of 11 years, without changing the chromosome content. Little is known about the selective forces on cell size, the mechanisms and the genetics of cell- and organ-size regulation.

In the taxon Plantago media L. (including $P$. stepposa Kuprian., Tutin et al., 1976), two cytotypes have been reported: diploids $(2 n=12)$ and tetraploids $(2 n=24)$ (Rahn, 1954; 1957). In Europe tetraploids have a wider geographical distribution than diploids (authors observations). Diploid and tetraploid $P$. media are morphologically very similar, but differ in number of ovules per capsule and length of the scape (Rahn, 1957). Rahn (1954) reported a regular meiosis in tetraploids with 12 bivalents, although occasional bridges were observed.

In this article we provide evidence for autotetraploidy in $P$. media from experimental hybridization, artificial polyploidization by colchicine treatment, and comparisons of allozyme pools. In addition natural and artificial cytotypes have been compared to determine how fertility and cell size are affected by autopolyploidization.

\section{MATERIALS AND METHODS}

Plant material. P. media is a wind pollinated, perennial species from dry, basic grasslands in Eurasia (Sagar and Harper, 1964). P. media is normally strongly self-incompatible, but occasionally selfcompatible plants occur (authors observations). Samples from the following populations were used: Diploid populations: Pyrenees (Gavarnie: $42 \cdot 45 \mathrm{~N}, 0 \cdot 15 \mathrm{~W})$; Col de Portalet: $42 \cdot 59 \mathrm{~N}, 0 \cdot 27 \mathrm{~W}$ ), Soviet Union (Orol region: $53 \cdot 00 \mathrm{~N}, 36 \cdot 05 \mathrm{E}$ ). Sympatric diploid-tetraploid population: Pyrenees (Formigal: $42.48 \mathrm{~N}, 0.24 \mathrm{~W}$ ). Tetraploid populations: Netherlands (Westervoort: $52 \cdot 00 \mathrm{~N}, 6 \cdot 00 \mathrm{E}$ ), Yugoslavia (Sarajevo: 43.50N, 18.25E), Pyrenees
(Andorra: $42 \cdot 35 \mathrm{~N}, 1 \cdot 40 \mathrm{E}$ ). From the Orol population, the sampling history is not known. All other samples were randomly-collected from natural populations (mature spikes collected from approximately 20 plants, growing at least one metre apart).

Cultivation conditions. Plants were grown in pots in a glasshouse $\left(18 \mathrm{~h} \mathrm{light,} 21^{\circ} \mathrm{C} / 6 \mathrm{~h}\right.$ dark, $\left.18^{\circ} \mathrm{C}\right)$. To prevent selfing, only female flowering (protogynous) parts of the spikes were used in the crosses. Seeds were harvested five weeks after crossing.

Colchicine treatment. A diverse seed sample from the diploid Gavarnie population was used. Colchicine $(0.25$ per cent in a 2 per cent dimethylsulfoxide solution) was applied as a drip with a syringe between the cotyledons of one week old seedlings. Colchicine was applied once a day for one, two or three successive days (treatment A, B or C, each 40 plants). Forty plants were treated with water as controls. Because only the shoot apex was affected, mixoploids with tetraploid shoots and diploid roots were obtained $\left(=\mathrm{C}_{0} 2 \mathrm{X} / 4 \mathrm{X}\right)$. From the roots, diploid grafts were made. Isogenic diploid and colchicine tetraploid $\mathrm{F}_{1}$ families (C4X) were made by crossing the same parents on the diploid and the tetraploid level to maximize heterozygosity (fig. 1).

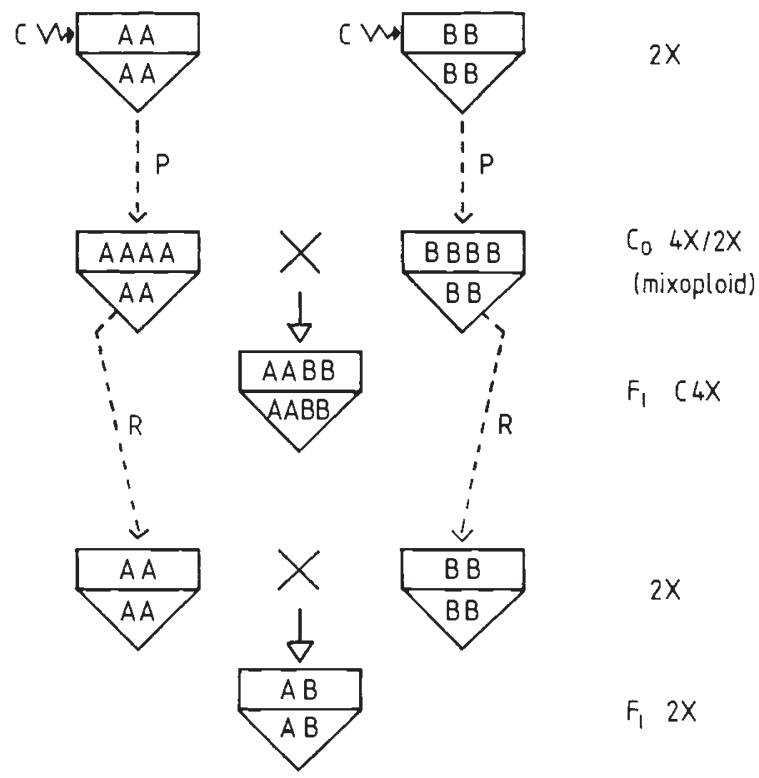

Figure 1 Derivation of isogenic diploid-colchicine tetraploid families. The upper part of the symbol represents the shoot, the lower part the root. (C: colchicine treatment P: polyploidization, $\mathbf{R}$ : root graft). 
Isogenic $2 \mathrm{X}$ and $\mathrm{C} 4 \mathrm{X}$ families have identical gene frequencies. Chromosome numbers were counted in squashed pollen mother cells and roottip cells stained by 2 per cent acetic orcein or the Feulgen method. Root-tips were pretreated with saturated aqueous 1-bromonaphthalene for $4 \mathrm{~h}$ at $4^{\circ} \mathrm{C}$ and fixed in Carnoy.

Measurements. Different cytotypes were compared for fertility and size characteristics in a randomized growth experiment in the glasshouse. Four different cytotypes were compared: natural $2 \mathrm{X}$, natural $4 X$, colchicine $4 X$ and tetraploid cytotype hybrids. Tetraploid hybrids had been occasionally obtained in $2 X-4 X$ crosses. Sixteen plants were used per cytotype, except for tetraploid hybrids in which only ten plants were available. All tetraploids were pollinated by natural tetraploids. Seed set was measured as the seed-ovule ratio. The average number of ovules per capsule was estimated from samples of 25 capsules per spike. Average pollen diameter and stomatal guard cell length of full grown scapes was estimated from samples of 50 cells in a 1:1 aceto orcein: glycerol mixture. Scape stomata were preferred to leaf stomata because of less size variation within plants. The percentage of filled pollen grains was used as an estimate of the male fertility (approximately 200 grains per sample).

Electrophoresis. Polyacrylamide gel electrophoresis was applied as described by Van Dijk and Van Delden (1981). Seven enzymes were selected: glutamate-oxaloacetate-transaminase (GOT), 6phosphogluconate dehydrogenase (6PGD), shikimate dehydrogenase (SHDH), leucine aminopeptidase (LAP), malic enzyme (ME), isocitrate dehydrogenase (IDH) and glyceraldehyde-3-phosphate dehydogenase (GA-3-PD) (all according to Van Dijk and Van Delden (1981)). For GOT the lithium borate $(p \mathrm{H} 8.3)$ buffer system of Roose and Gottlieb (1978) was used.

\section{RESULTS}

\section{Synthesis of colchicine tetraploids}

Colchicine strongly retarded growth and reduced survival in all treatments. Survival after 30 days was negatively correlated with the duration of the colchicine treatment (Treatment A: 95 per cent, B: 71 per cent and C: 24 per cent compared to the control). Flowering was also delayed (the first $\mathrm{C}_{0} 4 \mathrm{X} / 2 \mathrm{X}$ plant flowered 18 days later than the control). Of 70 investigated plants from treatments
$A$ and $B$, shoots of 30 plants were still $2 X, 36$ were $4 \mathrm{X}$ and four were $8 \mathrm{X}(2 n=8 \mathrm{X}=48)$. Octaploids had leathery, deformed, thick leaves, more delayed flowering and were completely sterile when crossed inter se. Many plants from treatment $\mathrm{C}$ showed these characteristics but since these plants did not flower, no chromosome counts were made. Artificial polyploidization did not affect selfincompatibility: no self-compatible $\mathrm{C}_{0} 4 \mathrm{X} / 2 \mathrm{X}$ or $\mathrm{C} 4 \mathrm{X}$ were found. $\mathrm{C}_{0} 4 \mathrm{X} / 2 \mathrm{X}$ mixoploids remained mixoploid during three years of cultivation in an experimental garden.

\section{Crossability}

The results from the crosses are given in table 1 . Great variation in seed number is caused by large differences in protogyny between plants (see materials and methods). Within both $2 \mathrm{X}$ and $4 \mathrm{X}$ ploidy levels, seed production in wide crosses was no lower than in within population crosses (table $1(a, b))$.

Even although diploids from the Pyrenees and the Soviet Union differ markedly in morphology (pubescence, leaf dimensions, seed weight) their

Table 1 Crossabilites in Plantago media in relation to ploidy level and geographical origin. $2 X \times 4 X$ crosses and reciprocal crosses are combined (PYR: Pyrenees (Andorra), SU: Soviet Union, NETH: The Netherlands, YUG: Yugoslavia)

\begin{tabular}{|c|c|c|}
\hline Populations & $\begin{array}{l}\text { Mean number } \\
\text { of seeds per } \\
\text { spike } \pm \text { s.d. }\end{array}$ & $\begin{array}{l}\text { Number } \\
\text { of crosses }\end{array}$ \\
\hline \multicolumn{3}{|c|}{ (a) within populations, within ploidy levels } \\
\hline PYR $(2 X)$ & $81 \pm 29$ & 20 \\
\hline SU $(2 X)$ & $100 \pm 24$ & 11 \\
\hline PYR (4X) & $38 \pm 22$ & 3 \\
\hline NETH (4X) & $98 \pm 54$ & 8 \\
\hline YUG $(4 X)$ & $107 \pm 25$ & 5 \\
\hline \multicolumn{3}{|c|}{ (b) Between populations, within ploidy levels } \\
\hline PYR $(2 X) \times \operatorname{SU}(2 X)$ & $111 \pm 32$ & 3 \\
\hline SU $(2 X) \times$ PYR $(2 X)$ & $73 \pm 26$ & 3 \\
\hline PYR $(4 X) \times$ NETH $(4 X)$ & 50 & 1 \\
\hline NETH $(4 X) \times$ YUG $(4 X)$ & $110 \pm 36$ & 3 \\
\hline YUG $(4 X) \times$ NETH $(4 X)$ & $58 \pm 14$ & 3 \\
\hline YUG $(4 X) \times$ PYR $(4 X)$ & $78 \pm 20$ & 3 \\
\hline \multicolumn{3}{|c|}{ (c) Between populations, between ploidy levels } \\
\hline PYR $(2 X) \times$ NETH $(4 X)$ & $0.6 \pm 0.9$ & 5 \\
\hline PYR $(2 X) \times$ PYR $(4 X)$ & $3 \cdot 8 \pm 3 \cdot 1$ & 13 \\
\hline PYR $(2 X) \times$ YUG $(4 X)$ & $2 \cdot 0 \pm 2 \cdot 8$ & 2 \\
\hline SU $(2 X) \times$ NETH $(4 X)$ & $0.3 \pm 0.5$ & 4 \\
\hline SU $(2 X) \times$ PYR $(4 X)$ & $1 \cdot 3 \pm 2 \cdot 5$ & 4 \\
\hline$S U(2 X) \times Y U G(4 X)$ & $0.0 \pm 0.0$ & 2 \\
\hline
\end{tabular}


hybrids show no reduction in fitness and can easily be back-crossed to either parent.

In crosses between ploidy levels however, the production of viable seeds was extremely low, irrespective of geographical origin (table 1(c)). Many seeds were shrivelled and empty and a high proportion of the filled seeds from these crosses did not germinate.

Table 2 shows the chromosome numbers from viable offspring of interploidy crosses. Most of the seeds from diploid seed parents were diploid and probably result from contamination with outcross haploid pollen. However 12 tetraploid offspring from diploid seed parents (all from the Pyrenees) were found, presumably from unreduced $2 \mathrm{X}$ eggs.

Table 2 Analysis of chromosome numbers of viable offspring from crosses between different ploidy levels

\begin{tabular}{|c|c|c|c|}
\hline CROSS & $2 X=12$ & $3 X=18$ & $4 X=24$ \\
\hline \multicolumn{4}{|l|}{$2 X \times 4 X^{*}$} \\
\hline LA $5 \times$ AN 14 & 8 & 0 & 0 \\
\hline LA $16 \times$ AN 22 & 6 & 0 & 0 \\
\hline LA $30 \times$ FO 2 & 2 & 0 & 0 \\
\hline LA $12 \times$ FO 4 & 1 & 0 & 2 \\
\hline LA $7 \times$ FO 3 & 0 & 0 & 5 \\
\hline FO $18 \times$ FO 7 & 2 & 0 & 5 \\
\hline Total & 19 & 0 & 12 \\
\hline \multicolumn{4}{|l|}{$4 \mathrm{X} \times 2 \mathrm{X}^{\dagger}$} \\
\hline FO $2 \times$ GG 6 & 0 & 3 & 1 \\
\hline S $29 \times$ LA 28 & 0 & 2 & 1 \\
\hline Total & 0 & 5 & 2 \\
\hline
\end{tabular}

* Five additional crosses without viable offspring.

$\uparrow$ Nine additional crosses without viable offspring.

Hybrid production was markedly unevenly distributed among crosses. No triploids were found among the offspring of diploid seed parents. However, two $4 \mathrm{X}-2 \mathrm{X}$ crosses produced some $3 \mathrm{X}$ seedlings, together with occasional $4 \mathrm{X}$ seedlings. Since no genetic markers were used, it cannot be ascertained whether these $4 \mathrm{X}$ seeds resulted from fertilization by unreduced $2 \mathrm{X}$ pollen or by contamination with reduced $2 X$ pollen from $4 X$ plants. Comparisons of viable seed production in intraand inter-ploidy crosses gives rough estimations of cytotype hybrid frequencies: 0.0123 for $4 \mathrm{X}$ hybrids in $2 \mathrm{X} \times 4 \mathrm{X}, 0.0084$ for $3 \mathrm{X}$ hybrids in $4 \mathrm{X} \times$ $2 \mathrm{X}$ and 0.0034 (maximal) for $4 \mathrm{X}$ hybrids in $4 \mathrm{X} \times$ 2X (assuming all $4 \mathrm{X}$ offspring were hybrids). Both triploid and tetraploid cytotype hybrids were vigorous. Tetraploid hybrids can readily be backcrossed to natural tetraploids. Triploid hybrids however were almost completely sterile.
No seeds were obtained from crosses between diploids and colchicine tetraploids. Since unrelated plants were crossed, effects of the selfincompatibility system can be excluded. Thus the colchicine treatment must have induced reproductive isolation between diploids and artificial tetraploids. By contrast, crosses between $\mathrm{C} 4 \mathrm{X}$ and natural $4 \mathrm{X}$ plants produced many seeds, most of them with 24 chromosomes although occasional aneuploids .were observed. These hybrids showed normal vigour. The original reproductive isolation between natural $2 \mathrm{X}$ and $4 \mathrm{X}$ was therefore bypassed by colchicine treatment.

\section{Characteristics of natural and artificial cytotypes}

In fig. 2 the mean values per cytotype are shown as percentages of the diploid means. The following values were measured in the diploids: seed set: 81.3 per cent; pollen stainability: $91 \cdot 2$ per cent; seed weight: $0.70 \mathrm{mg}$; stomatal guard cell length: $25.8 \mu \mathrm{m}$; pollen grain diameter ; $21.9 \mu \mathrm{m}$; number of ovules per capsule: 2.41 and scape length: $21 \cdot 7 \mathrm{~cm}$.

From fig. 2(a) and 2(b) it can be seen that colchicine tetraploids and tetraploid hybrids $(=2 \mathrm{X} \times 4 \mathrm{X})$ had high seed set and high percentages of filled pollen. The seed set of colchicine tetraploids is 79 per cent of the diploids and does not differ significantly from natural tetraploids. There were no significant differences between the cytotypes in pollen stainability.

Natural tetraploids had slightly but nonsignificant higher average seed weights, while seeds from tetraploid hybrids and colchicine tetraploids were respectively 15 and 38 per cent heavier (fig. $2(c))$. The ranking for pollen grain diameter was the same, but in this case all the differences were statistically significant $(P<0.05)$ (fig. $2(\mathrm{e}))$. Size differences are even more obvious in the estimated pollen volume (fig. $2(\mathrm{f})$ ). It is significant that tetraploid hybrids were intermediate between natural tetraploids and colchicine tetraploids in both seed weight and pollen size.

Stomatal guard cell length was lower in diploids than in the other cytotypes, which did not differ significantly from each other (fig. 2(d)). The number of ovules per capsule and the scape length differed between natural diploids and natural tetraploids (fig. 2(g), (h)). Both characters were not affected by colchicine treatment, whereas tetraploid hybrids were intermediate between the parental cytotypes. 

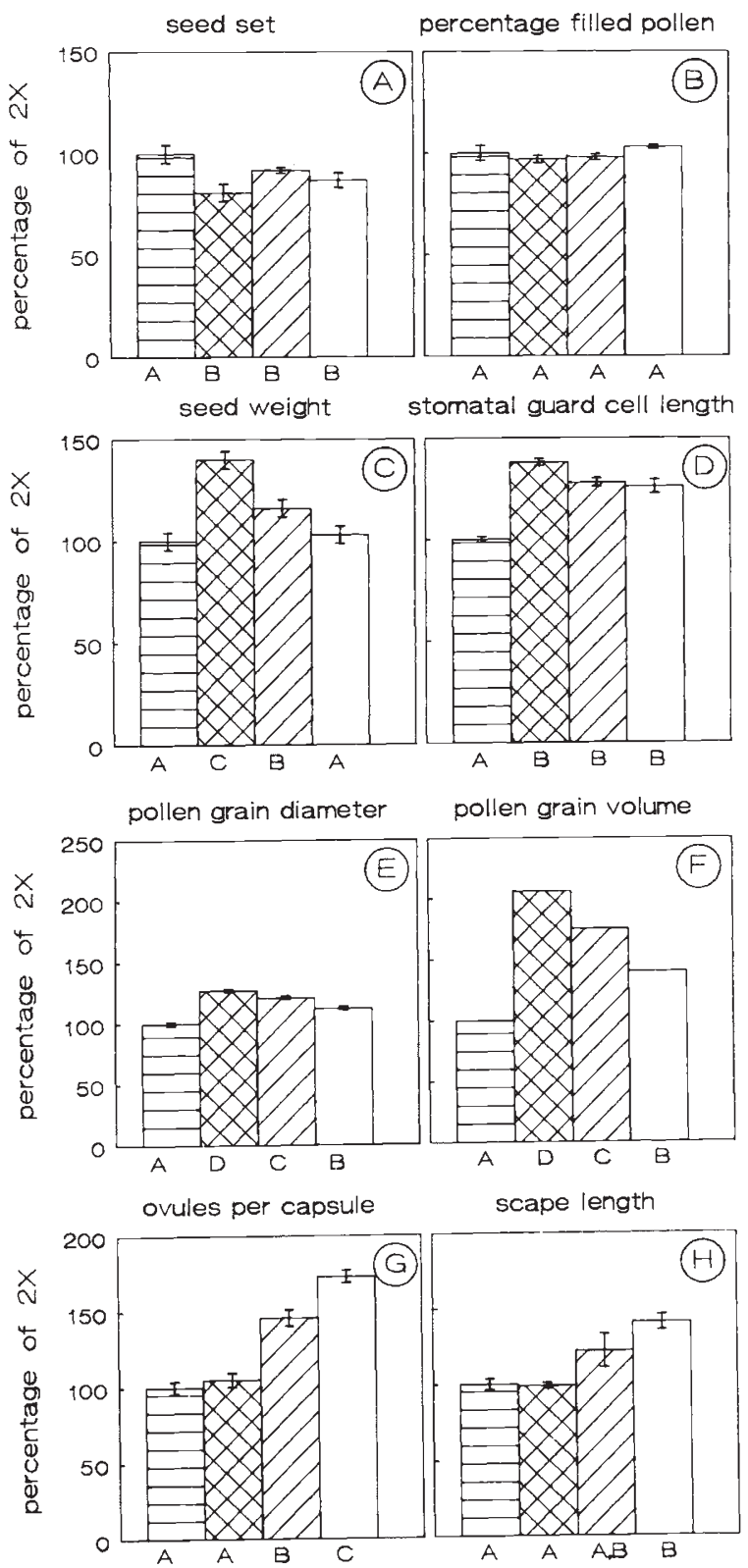

Figure 2 Comparisons between different cytotypes of Plantago media. Bars from left to right represent natural $2 \mathrm{X}$, colchicine $4 \mathrm{X}, 4 \mathrm{X}(2 \mathrm{X}-4 \mathrm{X})$ hybrid and natural $4 \mathrm{X}$ respectively (means as percentage of natural $2 \mathrm{X} \pm \mathrm{S}$.E.). Cytotypes that do not differ significantly are indicated by the same capital (ANOVA, $P<0.05$ ).

\section{Electrophoresis}

The results from the isozyme electrophoresis are shown in table 3 . Allelic segregation for five polymorphic loci was demonstrated in both diploids and tetraploids (data not shown). However in the
4X crosses it was not possible to discriminate between disomic and tetrasomic inheritance.

Tetraploids showed typical asymmetric heterozygotes, but no fixed heterozygosity was observed. In the tetraploids only Got-2 genotypic deduction was reliable enough to calculate gene frequencies in natural populations. In other loci the different heterozygotes could not be scored with certainty in most cases. Problems of interpretation were due to variation in allozyme activity and presence of null-alleles. In the case of $S h d h$ allozymes were triple banded and varied in activity. Therefore for these loci only presence or absence of allozymes is indicated. At the diploid level, all common alleles were found in the Soviet Union population as well as in the Pyrenean populations. Both Got loci showed marked differences in gene frequencies between the Soviet Union population and the Pyrenean $2 \mathrm{X}$ populations but since the sampling history of the Soviet Union population is not known it is uncertain whether this represents a real difference. All alleles found in the tetraploid populations were also present in the diploid populations although some rare alleles in diploid populations were not observed in tetraploids. All $4 \mathrm{X}$ populations were biallelic; no new tri- or quadri-allelic genotypes were seen. Monomorphic loci were identical in the diploid and tetraploid material.

\section{DISCUSSION}

\section{Evidence for autotetraploidy}

All together the results strongly suggest that $P$. media is an autopolyploid species-complex. Diploids and tetraploids are morphologically very similar but distinct from other Plantago species. No barriers to wide crosses were found within ploidy levels. Strong reproductive barriers exist between ploidy levels, however occasionally vigorous $3 \mathrm{X}$ and $4 \mathrm{X}$ hybrids were produced. The reproductive barriers between the cytotypes could be broken down as well as introduced by chromosome doubling by colchicine treatment. Finally no allozymes were found in the $4 \mathrm{X}$ samples that did not occur in the $2 \mathrm{X}$ samples.

Recent detailed cytogenetic investigations fully support the autotetraploid origin of $P$. media $(\mathrm{Dr}$ J. S. Parker, personal communication). Quadrivalents are found at metaphase I and more significantly, at pachytene, chromosomes are usually associated as quadrivalents with numerous pairing partner exchanges. In viable triploid hybrids observations up to six trivalents in pollen mother 
Table 3 Presence and frequencies of allozymes in some $2 \mathrm{X}$ and $4 \mathrm{X}$ populations of Plantago media (SU: Soviet Union, GAV: Gavarnie, POR: Portalet, FOR: Formigal, AN: Andorra, NETH: Netherlands, YUG: Yugoslavia). Rm is the relative migration of allozymes (Bromophenol blue or borate $=100$ )

\begin{tabular}{|c|c|c|c|c|c|c|c|c|c|}
\hline & \multirow[b]{2}{*}{$\mathrm{Rm}$} & \multicolumn{4}{|l|}{$2 X$} & \multicolumn{4}{|l|}{$4 X$} \\
\hline & & SU & GAV & POR & FOR $2 X$ & FOR $4 \mathrm{X}$ & $\mathrm{AN}$ & NETH & YUG \\
\hline Got 1 & $\begin{array}{l}22 \\
25 \\
28\end{array}$ & $\begin{array}{l}0.00 \\
0.06 \\
0.94\end{array}$ & $\begin{array}{l}0.00 \\
1 \cdot 00 \\
0.00\end{array}$ & $\begin{array}{l}0.22 \\
0.78 \\
0.00\end{array}$ & $\begin{array}{l}0.06 \\
0.94 \\
0.00\end{array}$ & $\begin{array}{l}- \\
+ \\
+\end{array}$ & $\begin{array}{l}- \\
+ \\
+\end{array}$ & $\begin{array}{l}- \\
+ \\
+\end{array}$ & $\begin{array}{l}- \\
+ \\
+\end{array}$ \\
\hline Got 2 & $\begin{array}{l}16 \\
18 \\
21\end{array}$ & $\begin{array}{l}0.00 \\
0.09 \\
0.91\end{array}$ & $\begin{array}{l}0.02 \\
0.98 \\
0.00\end{array}$ & $\begin{array}{l}0.02 \\
0.98 \\
0.00\end{array}$ & $\begin{array}{l}0.06 \\
0.94 \\
0.00\end{array}$ & $\begin{array}{l}0.00 \\
0.96 \\
0.04\end{array}$ & $\begin{array}{l}0.00 \\
1.00 \\
0.00\end{array}$ & $\begin{array}{l}0.00 \\
0.69 \\
0.31\end{array}$ & $\begin{array}{l}0.00 \\
0.69 \\
0.31\end{array}$ \\
\hline $6 \mathrm{Pgd} 1$ & $\begin{array}{l}35 \\
38 \\
40\end{array}$ & $\begin{array}{l}? \\
? \\
?\end{array}$ & $\begin{array}{l}0.34 \\
0.65 \\
0.01\end{array}$ & $\begin{array}{l}0.20 \\
0.80 \\
0.00\end{array}$ & $\begin{array}{l}0.50 \\
0.50 \\
0.00\end{array}$ & $\begin{array}{l}+ \\
+ \\
-\end{array}$ & $\begin{array}{l}+ \\
+ \\
-\end{array}$ & $\begin{array}{l}+ \\
- \\
-\end{array}$ & $\begin{array}{l}+ \\
+ \\
-\end{array}$ \\
\hline $6 \mathrm{Pgd} 3$ & $\begin{array}{l}22 \\
24\end{array}$ & $\begin{array}{l}0.00 \\
1.00\end{array}$ & $\begin{array}{l}0.07 \\
0.93\end{array}$ & $\begin{array}{l}0.00 \\
1.00\end{array}$ & $\begin{array}{l}0 \cdot 18 \\
0 \cdot 82\end{array}$ & $\begin{array}{l}+ \\
+\end{array}$ & $\begin{array}{l}+ \\
+\end{array}$ & $\begin{array}{l}+ \\
+\end{array}$ & + \\
\hline Shdh & $\begin{array}{l}20 \\
26 \\
32\end{array}$ & $\begin{array}{l}0.00 \\
0.27 \\
0.63\end{array}$ & $\begin{array}{l}0.04 \\
0.48 \\
0.48\end{array}$ & $\begin{array}{l}0.00 \\
0.42 \\
0.58\end{array}$ & $\begin{array}{l}0.00 \\
0.20 \\
0.80\end{array}$ & $\begin{array}{l}- \\
+ \\
+\end{array}$ & $\begin{array}{l}- \\
+ \\
+\end{array}$ & $\begin{array}{l}- \\
+ \\
+\end{array}$ & $\begin{array}{l}- \\
+ \\
+\end{array}$ \\
\hline Lap & 21 & $1 \cdot 00$ & $1 \cdot 00$ & $1 \cdot 00$ & $1 \cdot 00$ & $1 \cdot 00$ & 1.00 & $1 \cdot 00$ & $1 \cdot 00$ \\
\hline $\mathrm{Me}$ & 17 & 1.00 & 1.00 & $1 \cdot 00$ & $1 \cdot 00$ & $1 \cdot 00$ & $1 \cdot 00$ & $1 \cdot 00$ & $1 \cdot 00$ \\
\hline Idh & 26 & $1 \cdot 00$ & $1 \cdot 00$ & $1 \cdot 00$ & $1 \cdot 00$ & $1 \cdot 00$ & $1 \cdot 00$ & $1 \cdot 00$ & $1 \cdot 00$ \\
\hline Ga3pd & 14 & $1 \cdot 00$ & $1 \cdot 00$ & $1 \cdot 00$ & 1.00 & $1 \cdot 00$ & $1 \cdot 00$ & $1 \cdot 00$ & $1 \cdot 00$ \\
\hline$N$ (plants) & & 41 & 66 & 32 & 17 & 17 & 42 & 30 & 30 \\
\hline
\end{tabular}

cells indicate strong homology of the $2 X$ and $4 X$ genomes. Also RFLP analysis shows close relatedness between 2X and 4X CpDNA (Dr R. Lumaret and $\mathrm{Dr} \mathrm{K}$. Wolff, personal communication). Finally reproductive barriers between $P$. media and other Plantago species are strong: Rahn (1957) failed to hybridise $P$. media (both $2 \mathrm{X}$ and $4 \mathrm{X}$ ) with $P$. lanceolata; $P$. major; $P$. coronopus; $P$. maxima or $P$. camtschatica.

Recently a number of other well documented cases of autopolyploidy have been reported (e.g., Dactylis glomerata (Lumaret, 1988); Tolmiea menziesii (Soltis and Rieseberg, 1986); Lathyrus pratensis (Brunsberg, 1977); Heuchera micrantha (Ness et al., 1989; Soltis and Soltis, 1989); Vaccinium corymbosum (Krebs and Hancock, 1989)). This suggests that autopolyploidy is more common than once thought.

\section{Mechanism of reproductive isolation}

The reproductive isolation between cytotypes is due to differences in ploidy level per se and not to genome incompatibility, since hybrids between natural and colchicine tetraploids have high vigour. The ontogeny of the fertilization process shows that the barrier is post-zygotic. No abnormalities are observed until about ten days after pollination. At this time the endosperm development stops, strongly indicating that seed abortion is caused by endosperm collapse. This phenomenon ("triploid block") is well known in inter-ploidy crosses (Levin 1978; Johnston et al., 1980; Parrot and Smith, 1986). The reason for abnormal endosperm development in inter-ploidy crosses is probably a deviation from the maternal : paternal genome ratio of $2: 1$ in the endosperm ("endosperm balance number hypothesis", Johnston et al., 1980). In $2 \mathrm{X}-4 \mathrm{X}$ crosses this ratio is $1: 1$ and in $4 X \times 2 X$ crosses it is $4: 1$. However for unreduced eggs in $2 X-4 X$ crosses, the $2: 1$ ratio is restored and endosperm and embryos develop normally. The endosperm genome ratio may also explain why rare viable $3 \mathrm{X}$ hybrids are only found in $4 X-2 X$ crosses: failure of fusion of polar nuclei, would restore the viable parental genome ratio. This would not be so in the reciprocal cross. The presence of cytotype hybrids indicates that some gene flow between cytotypes is possible in sympatric populations. 


\section{Effects of polyploidization on fertility}

Seed set (the number of ovules becoming seeds) was significantly lower in natural tetraploids than in diploids. A similar difference was observed in previous experiments. This difference may be caused by meiotic aberrations in natural tetraploids, but other factors like stronger zygote competition may also be involved. Total seed production however is higher in natural tetraploids since reduced seed set is over-compensated by a higher number of ovules per capsule.

Seed set in colchicine tetraploids of $P$. media is high in comparison to colchicine tetraploids in other plant species (Gottschalk, 1976). Quadrivalents in colchicine tetraploids are found at metaphase 1 , although at a rather low frequency due to the low chromosome number and low chiasmata frequency (Dr J. S. Parker, personal communication). Although natural tetraploids have a significantly lower quadrivalent frequency than colchicine tetraploids this difference is not reflected in seed set and pollen stainability.

\section{Effect of polyploidization on cell volume}

Pollen grain volume of colchicine tetraploids was doubled compared to diploids, whereas pollen grain volume of natural tetraploids was only 40 per cent larger. A similar difference was observed by Rahn (1957). Stomatal guard cell length is difficult to compare between cytotypes, since scape length itself differs between cytotypes. Colchicine tetraploids however show clear size increase compared to diploids. Seeds from colchicine were on average 40 per cent heavier than seeds from either diploids or natural tetraploids. It is not known whether the difference in seed weight between natural and artificial tetraploids is caused by differences in cell number or cell size. Other gigaseffects could be seen in the larger leaves and flowers as well as thicker spikes of colchicine tetraploids. Natural tetraploids do not show these gigas-effects.

Tetraploid hybrids showed partial gigascharacteristics. These hybrids resulted from a nonreduced $2 \mathrm{X}$ egg cell of the $2 \mathrm{X}$ mother and a reduced $2 \mathrm{X}$ male gamete from a natural $4 \mathrm{X}$ father. The unreduced $2 \mathrm{X}$ genomes have a similar cell size effect to the genomes doubled by colchicine treatment. These results indicate that natural $2 X$ and $4 \mathrm{X}$ differ in genetic cell size factors and that the effects are additive.

In two other Plantago-species, $P$. major and $P$. coronopus, no differences in cell size were found beween diploids and natural polyploids (Favarger and Vasudevan, 1972; Gorenflot, 1960). However in $P$. coronopus artificial doubling by colchicine treatment markedly increased cell size of the $4 X$ (derived from $2 \mathrm{X}$ ) and of the $8 \mathrm{X}$ (derived from natural 4X) (Gorenflot, 1960; 1963). At the interspecific level, North American Chasmogamous Plantago species show no differences between $2 \mathrm{X}$ and $4 \mathrm{X}$ in pollen grain diameter (Bassett and Crompton, 1968). Thus differences in cell size between natural and artificial polyploids seem to be a general phenomenon within the genus Plantago. Similar differences have also been found in other genera: in both Gymnaster savatieri and Chrysanthemum sp. natural polyploids had smaller stomatal guard cell length than artificial polyploids (Tanaka, 1953).

Both number of ovules per capsule and scape length, two discriminating characters between $2 \mathrm{X}$ and 4X P. media (Rahn, 1957), were not affected by artificial polyploidization. Therefore it can be concluded that these differences are not a direct consequences of genome multiplication. This is supported by the fact that $2 \mathrm{X}-4 \mathrm{X}$ hybrids lie between their parental types for these characters, in contrast to cell size characteristics.

\section{Selection against large cells after polyploidization?}

The differences found between artificial and natural polyploids suggest that natural selection has been operating against large cells. Clearly increase in cell volume has important functional consequences (Lewis, 1980; Levin, 1983; Cavalier-Smith, 1985). Cell volume is under both nucleotypic and genetic control, both of which may be modified (Cavalier-Smith, 1985; Baer, and Schrader, 1985). In $P$. media natural $4 \mathrm{X}$ and colchicine $4 \mathrm{X}$ have the same DNA content per cell (Dr J. S. Parker, personal communication). It has been suggested that increased gene dosage rather than total DNA content may be the cause of the volume increase in artificial autopolyploids (Cavalier Smith, 1985). Our results indicate that cell size in natural tetraploid $P$. media is regulated by additive genes. Modifications of gene expression may be expected to parallel cell volume changes in order to maintain optimal metabolical concentrations in cells. There are indications that amounts of cellular constituents are reduced in natural polyploids compared to artificial polyploids (e.g., rRNA cistron number, (Cullis and Davies, 1974) and amount of ribulose-1,5-bisphosphate-carboxylase, Leech et al., 1985)). 
In $P$. media natural tetraploids have smaller pollen grains than artificial tetraploids, but longer scapes and scape stomatal guard cells. Successful wind pollination depends on large numbers of small pollen grains and exposed reproductive structures (Whitehead, 1983). In Plantago chasmogamous species have smaller pollen grains and higher pollen numbers than cleistogamous species (Primack, 1978). Primack (1978) showed that wind dispersal of large pollen grains was reduced. In addition the costs of pollination in terms of biomass are higher in larger pollen grains. Selection for increased pollination efficiency may be strong in an out-crossing species like $P$. media. This could involve selection both for smaller pollen grains as well as longer scapes (and longer scape cells).

Different cell types may be subjected to different selection regimes. On the other hand cell sizes are not independent, and this may cause correlated selection responses. This may explain why natural diploid and tetraploid $P$. media have the same seed size, although gigas-seed itself might be adaptive (Stebbins, 1971; Solbrig, 1980).

Acknowledgements: We are grateful to Dr R. Bijlsma and Dr J. S. Parker for comments on earlier versions of the manuscript. This study was supported by the Foundation of Fundamental Biological Research (BION), which is subsidized by the Netherlands Organization for Scientific Research (NWO).

\section{REFERENCES}

BAER, G. R. AND SCHRADER, L. E. 1985. Inheritance of DNA concentration, and cellular contents of soluble protein, chlorophyll, ribulose biphosphate carboxylase and pyruvate, $\mathrm{Pi}$ dikinase activity in maize leaves. Crop Sc., 25 , 916-923.

BASSETT, I. J. AND CROMPTON, C. W. 1968. Pollen morphology and chromosome numbers in the family Plantaginaceae in North America. Can. J. Bot. , 46, 349-361.

BRUNSBERG, K. 1977. Biosystematics of the Lathyrus pratensis complex Opera bot., 42, 1-78 (Stockholm).

CAVALIER-SMITH, T. 1985. Cell volume and the evolution of eukaryotic genome size. In Cavalier-Smith, T. (ed.) The Evolution of Genome Size. Wiley and Sons, pp. 105-184.

CLAUSEN, J. D., KECK, D. D. AND HIESEY, W. M. 1945. Experimental studies on the nature of species. II. Plant evolution through amphiploidy and autoploidy, with examples from the Madiiae. Carnegie Inst. Wash, Publ., 654.

CULlis, C. AND DAVIES, D. R. 1974. Ribosomal RNA cistron number in a polyploid series of plants. Chromosoma, 46 , 23-28.

DEWET, J. M. J. 1980. Origins of polyploids. In Lewis, W. H. (ed.) Polyploidy, Biological Relevance, Plenum Press, New York, pp. 3-15.
DIETRICH, H. 1975. Cytologische untersuchungen innerhalb der familie der Plantaginaceae II. Zusammenstellung bekannter Chromosomenzahlen und der Vergleich zwischen Grundzahl und Lebensdauer. Wissenschaftlisches Zeitschrift Friedrich Schiller Universitaet Jena, Mathematisch-Naturwissenschaftliche Reie 24: 437-461.

DIETRICH, H., 1980. Cytologische untersuchungen innerhalb der familie der Plantaginaceae III. Cytotaxonomische Ergebnisse. Wissenschaftlisches Zeitschrift Friedrich Schiller Universitaet Jena, Mathematisch-Naturwissenschaftliche Reie 29, 559-587.

FAVARGER, C. AND VASUDEVAN, K. N. 1972. Etude cytologique et morphologique des populations de Plantago major L. et de Plantago lanceolata L. de l'himalaya occidental: comparaison avec des plantes de suisse. Bull. Soc. Neuchat. Sci. Nat., 95, 63-74.

Gorenflot, R. R. 1960. La Polyploidie chez Plantago coronopus. Rev. Cyt. Biol. Veget., 22, 77-108.

GORENFLOT, R. R. 1963). Autoallopolyploidie experimentale chez Plantago coronopus L. Bull. Soc. Bot. Fr., 110, 76-91.

GotTsChalk, w. 1976. Die Bedeutung der Polyploidie fur die Evolution der Pflanzen. Fisher, Stuttgart.

GRANT, v. 1981. Plant Speciation. Columbia University Press, New York.

JOHNSTON, S. A., DEN, NIJS, T. P. M., PELOQUIN, S. J. AND HANNEMAN, JR., R. E. 1980. The significance of genetic balance to endosperm development in interspecific crosses. Theor. Appl. Genet., 57, 5-9.

KREBS, S. L. AND HANCOCK, J. F. 1989. Tetrasomic inheritance of isoenzyme markers in the highbush blueberry, Vaccinium corymbosum L. Heredity, 63, 11-18.

LEECH, R. M., LEESE, B. M. AND JELLINGS, A. J. 1985. Variation in celular ribulose-1,5-bisphosphate-carboxylase contents in leaves of Triticum genotypes at three levels of ploidy. Planta, 166, 259-263.

LEVIN, D. A. 1978. The origin of isolation mechanisms in flowering plants. In Hecht, M. H., Steere, W. C. and Wallace, B. (eds) Evolutionary Biology 11, Plenum, New York, pp. 185-317.

LEVIN, D. A. 1983. Polyploidy and novelty in flowering plants Am. Nat., 122, 1-25.

LEWIS, W. H. 1980. Polyploidy in species populations. In Lewis, W. H. (ed.) Polyploidy, Biological Relevance, Plenum Press, New York, pp 104-143.

LUMARET, R. 1988. Cytology, genetics and evolution in the genus Dactylis. CRC Crit. Rev. Pl. Sci., 7, 55-91.

NESS, B. D., SOLTIS, D. E. AND SOlTIS, P. S. 1989. Autopolyploidy in Heuchera micrantha (Saxifragaceae). Am. J. Bot., $76,614-626$.

PRIMACK, R. B. 1978. Evolutionary aspects of wind-pollination in the genus Plantago (Plantaginaceae). New Phytol., 81, 449-458.

PARROTT, W. A. AND SMITH, R. R. 1986 Evidence for the existence of endosperm balance number in the true clovers (Trifolium spp.). Can. J. Genet. Cytol., 28, 581-586.

RAHN, K. 1954. Experimental and cytological studies in Plantago media. Bot. Tidsskr., 51, 300-307.

RAHN, K. 1957. Chromosome numbers in Plantago. Bot. Tidsskr., 53, 369-378.

ROOSE, M. L. AND GOTTLIEB, L. D. 1978. Stability of structural gene number in diploid species with different amounts of nuclear DNA and different chromosome numbers. Heredity, 40, 159-163.

SAGAR, G. R. AND HARPER, J. L. 1964. Biological flora of the British Isles Plantago major L., Plantago media L. and Plantago lanceolata L. J. Ecol. 52, 189-221. 
SOLBRIG, O. T. 1980. Principles of demographic analysis applied to natural polyploid populations. In Lewis, W. H. (ed.) Polyploidy, Biological Relevance, Plenum Press, New York, pp. 537-538.

SOlTIS, D. E. AND RIESEBERG, L. H. 1986. Autopolyploidy in Tolmiea menziesii (Saxifragaceae): genetic insights from enzyme electrophoresis. Amer. J. Bot., 73, 310-318.

SOLTIS, D. E. AND SOLTIS, P. S. 1989. Tetrasomic inheritance in Heuchera micrantha (Saxifragaceae). J. Hered., 80, 123126.

StebBins, G. L. 1971. Chromosomal Evolution in Higher Plants. Arnold, London.

STEBBiNS, G. L. 1980. Polyploidy in plants: unsolved problems and prospects. In: Lewis, W. H. (ed.) Polyploidy, Biological Relevance, Plenum Press, New York, pp. 495-520.

Stebrins, G. L. 1985. Polyploidy, hybridization and the invasion of new habitats. Ann. Missouri Bot. Gard., 72, 824-832.

STEBBINS, G. L. AND DAWE, J. C. 1987. Polyploidy and distribution in the European flora: a reappraisal. Bot. Jahrb. Syst. Pfl. Gesch. Pfl Geogr., 108, 343-354.

TANAKA, R. 1953. On difference of the cell volume between natural polyploids and artificial polyploids. Jap. J. Genet., $28,110-115$.
TROMBETtA, v. 1942. The cytonuclear ratio. Bot. Rev., 8, 317336.

TUTIN, T. G., HEYWOOD, V. H., BURGES, N. A., MOORE, D. M., VALENTINE, D. H., WALTERS, S. M. AND WEBB, D. A. (eds) 1976 Flora Europaea. Cambridge University Press, Cambridge.

VAN DIJK, H. AND VAN DELDEN, W. 1981. Genetic variability in Plantago species in relation to their ecology. Part 1: genetic analysis of the allozyme variation in $P$. major subspecies. Theor. Appl. Genet., 60, 285-290.

VON WETTSTEIN, F. 1937. Experimentelle untersuchungen zum artbildungsproblem I. zellgossenregulation und fertilwerden einer polyploiden Bryum-sippe. Zeitsch. ind. Abst. Vererb., 74, 34-53.

WATANABE, K. 1983. Studies on the control of diploid-like meiosis in polyploid taxa of Chrysanthemum 4. Colchiploids and the process of cytogenetical diploidization. Theor. Appl. Genet., 66, 9-14.

WHITEHEAD, D. R. 1983. Wind pollination: some ecological and evolutionary perspectives. In Real L. (ed.) Pollination Biology, Academic Press London, pp. 97-108. 